In remembrance of, and inspired by, Professor Jeanette Rhedding-Jones

In the first lesson, the chairs in the classroom were rearranged, and we sat in a circle without desks or notebooks

in front of us. We faced each other, and I noticed that she was wearing green tights. Her legs were encapsulated in green tights.

Later, I learned that she was wearing green as a symbol. She was wearing green as a symbol of feminism. I knew little of this symbol before I met her and came to know her knowledge. Then again, I knew little of feminism before I met Jeanette. She introduced me to both feminism and poststructuralism.

Her legs may have been encapsulated in green tights, but she and the knowledge that she produced have found passages far beyond her skin and bodily presence.

Her memory I carry in and beyond my heart. Her memory I carry in and beyond my hands.

\title{
The concept of the dispositive: Methodological pathways to critical educational research
}

Bente Ulla Bente.Ulla@hiof.no

$\varnothing$ stfold University College and Oslo University

\section{Abstract}

This paper aims to use the Foucauldian concept of the dispositive as a methodological pathway to critical educational research. Throughout the paper, I consider the concept as a passage through which to extract and dwell upon the discursive configurations and reconfigurations of epistemic conditions regarding kindergarten teachers' professionalism. In an ongoing study, I contribute to critical research on the increasing demand for mapping children's skills in contemporary kindergartens by exploring the nuances of kindergarten teachers' knowledge, judgment and practice. The concept of the dispositive constructs a pathway for centring attention on the interplay between bodies and power technologies. I have further chosen to connect this to processes of how kindergarten teachers are made subjects in space and time. Through my choice of foci and methodology, I theorise and problematise regarding how these ensembles intertwine in a play of knowledge/power in the context of the kindergarten as a modern welfare institution. 
Key words: dispositive, methodology, kindergarten, bodies, knowledge/power

\section{Introduction}

This article attempts to explore how Foucault's dispositive, as well as the closely connected concept of apparatus, might be put to work methodologically in critical educational research. First and foremost, this article is written as a conceptual paper, and the weight of the text centres on theoretical and methodological arguments, although some empirical examples are included in the discussion. The aim is to question how I can draw upon the chosen concepts to analyse the close relationship between power and knowledge in the increasingly emergent practices and policies of mapping children's skills in Norwegian kindergartens. ${ }^{1}$ The article emphasises dispositive ensembles as exemplary in understanding constitutions of disciplinarian forces through relations of power, knowledge and bodies. In this text, I do not distinguish between dispositive and apparatus; rather, I use the concepts interchangeably. ${ }^{2}$ Foucault (1977/1980a) uses the concepts to point to heterogeneous relations that come to play in the genesis, or re-formation, of a practice or an institution, among others.

Working methodologically with these concepts opens up the possibility of exploring the enweaved complexities that I face in my ongoing critical educational research. The concept of the apparatus supports my exploration of how relations between technologies, discourses and materiality are being shaped and re-shaped in contemporary kindergartens. The concepts resist a contrast between micro and macro levels and suggest a fusion of foci between these levels when analysing the discursive configurations and reconfigurations of kindergarten teachers' professional knowledge.

The concept of the apparatus gives me an opportunity to center my attention on the interplay between bodies and power technologies; in my study, I have chosen to read this as processes of how kindergarten teachers are made subjects in space and time. The games of truth and the practices of power are central elements in these processes, all of which are inextricably involved in the concept of the dispositive. In my ongoing study, I have examined, in particular, how surveillance is being installed in contemporary kindergartens as well as how certain coordinates of knowledge support this act. Following Foucault, I read this act as being linked to the political technology of the body, and by dwelling on bodily aspects as bricks of surveillance technology, I may, with the support of the concept of the apparatus, contribute certain nuances regarding how new fields of rationality may install and re-shape themselves in the kindergarten institution.

Foucault uses the concept of governmentality to expand the notion on how power installs itself through modern welfare institutions. He embellishes patterns of how qualities of the population are governed through the welfare state and welfare policy. Further he sets out another level of governmentality linked to the level of the subject. Through this, Foucault elaborates on how power arranges and produces the government of one's self and of others (Foucault, 1982/1994).

\footnotetext{
${ }^{1}$ Kindergarten is chosen as a translation of the Norwegian word Barnehage. It refers to an ECEC (early childhood education and care) institution providing pedagogical settings for children aged zero to six and contains structures of both family day care and preschools. The responsibility for ECEC falls under the Ministry of Education, and its kindergartens are regulated by the 'Kindergarten Act' (Kunnskapsdepartementet, 2006) and informed by the national curriculum, 'The Framework Plan for the Contest and Task of Kindergarten' (Kunnskapsdepartementet, 2011a).

${ }^{2}$ I am aware that interchanging the concepts of dispositive and apparatus ignores problems that have been encountered in translations from French and Italian into English (Bussolini, 2010). I have been limited to English and Scandinavian translations of Foucault's work, and I realise that this might have certain implications relating to the use of these concepts. Regardless, I have used the concepts as steppingstones into critical educational research, and I stand by that choice as long as it works as a productive thinking tool.
} 
Apparatuses may be read as the strategy in the processes of governmentality, of which the conduct of conduct may be installed in individuals.

\section{Reshaping the foci}

Over the last decades, there has been a visible shift in the terrain of knowledge and power in relation to early childhood education and care (Bloch et al., 2003; Popkewitz \& Fendler, 1999; Popkewitz et al., 2001). This shift of tasks and practices has also affected Norwegian kindergartens, which have been critically examined (Otterstad \& Braathe, 2010; Solbrekke \& $\varnothing$ strem, 2011). Education has been a cornerstone of the modern welfare state, supported by an underlying faith in its contribution to equality and social justice. However, contemporary conditions have led to new shifts regarding the notion of inclusion as educational policies are being reformulated and delimited (Arnesen \& Lundahl, 2006). Kindergarten teachers are given the task of administrating individuals and of fixing problems of social inclusion/exclusion through surveillance. However, the shifting tasks are not a complete turnabout for Norwegian kindergartens. The kindergarten teacher has a long history of administrating individuals and of observing children's early development.

Notwithstanding, in contemporary kindergartens, the foci on the registration and documentation of children's learning and of more specific learning outcomes/abilities/impairments/skills connected to language are installing themselves in new configurations. I am reading this re-shaping of foci as an aspect of dispositive ensembles. I do this as a methodological entry into critical research, and the aim of the study is to contribute to the field through nuances of kindergarten teachers' knowledge, judgment and practices in relation to the increasing demand for mapping children's skills in contemporary kindergartens.

I have gathered empirical material from Norwegian kindergartens through diverse methods: observations, interviews and public documents. Through reading, talking, seeing, listening, sitting and moving inside kindergartens, I have experienced a growing interest for bodily aspects relating to knowledge, judgement and practice. The stories of bodies circulate when the kindergarten teachers talk. The teachers articulate their gut feelings through the manner in which they use their eyes and ears and how they move around the rooms. Bodily aspects are repeated in the statements, and through observing, I have taken notes on grasping hands, butts on floors, sounds entering ears, doors excluding and including participants, eyes steering and shoulders slowly moving. These are all elements in heterogeneous ensembles of discourses; further, they are all elements of the dispositive, a net connecting the elements and making it possible for pedagogy to be re-shaped in relation to contemporary conditions.

Here, I follow Rhedding-Jones (2008) who points to how the focus of a critical researcher may examine power circulations:

[...] how power has a series of affects, and it operates in local and specific sites, as everyday institutional practices. If we see techniques, strategies and tactics that enable productive and repressive moments, we can research power's circulation. (Rhedding-Jones, 2008, p. 35)

Through the choice of foci and methodology, I theorise and problematise the manner in which these ensembles intertwine in a play of knowledge and power in the context of the kindergarten as a modern welfare institution. Through this approach, I can provide new nuances of everyday life in kindergartens. Further, this methodology allows me to problematise the manner in which knowledge constructions of the kindergarten institution are as leaky as the humans and the materials they are made of. 


\section{Presenting examples of policy statements}

To exemplify how this task may be given to the Norwegian kindergarten teachers, I have constructed a cut out of a pamphlet distributed by Oslo municipality ${ }^{3}$ to the kindergarten teachers within the city. The pamphlet offers free post-graduate education to kindergarten teachers under the headline: Språkarbeid og barns språkutvikling og språkkartlegging [Language work and children's language development and language mapping].

First text-cut:

Noen barn har forsinket språkutvikling, noen har språkvansker. Stadig flere barn i Oslo er flerspråklige. Barnehagene kan gi disse barna en god start på livet ved å gi dem en målrettet oppfølging og språkstimulering.
English translation: Some children have delayed language development, some have language difficulties. An increasing number of children in Oslo are multilingual. Kindergartens can give these children a good start in life with targeted follow-up and stimulation.

Second text-cut:

Målet er at alle barn skal kunne tilstrekkelig norsk til å følge ordinær opplæring fra skolestart, noe ett av fire barn ikke gjør i dag. Tidlig innsats ut fra hvert barns potensial er viktig.

English translation: The aim is for all children to
have adequate proficiency in Norwegian in
order to follow basic training when they start
school; today, one in four children do not have
adequate proficiency. Early intervention based
on each child's potential is important.

English translation: The aim is for all children to have adequate proficiency in Norwegian in order to follow basic training when they start school; today, one in four children do not have on each child's potential is important.

The first text-cut from the pamphlet states goals connected to learning outcomes, which are further linked to arguments about a 'good' in life. I will later return to how statements of 'goodness' represent a rationality repeated at different levels of policy documents. But first, I choose to dwell upon the statement concerning learning outcomes. These outcome-related goals are stated through the local community and are distinguishable from policy documents at the governmental level. In the national curriculum (Kunnskapsdepartementet, 2011a), the expectations regarding the youngest citizens' learning outcomes are not stated. The European Qualifications Framework (EQF), as set out by the European Commission, has been implemented in the national educational system of Norway (European Commission, 2008; Kunnskapsdepartementet, 2011b). The EQF establishes mechanisms for lifelong learning policy and a description of eight levels of learning outcomes, ranging from 'basic' at the first level to 'advanced' at level eight. The indicators of learning outcomes are descriptions of 'what a learner knows, understands and is able to do"' (European Commission, 2008).

Kindergarten is recognised as a part of the educational system in Norway, though it is not compulsory, and the first level of the EQF has currently been left open for adaptation into the Norwegian setting. Level 1 is marked 'Open' and further states that no qualifications are enrolled at this level (Kunnskapsdepartementet, 2011b, p. 16). Taking the elements of an apparatus into

\footnotetext{
${ }^{3}$ The pamphlet was dispatch January 2013, via mail, to all the kindergartens of Oslo municipality. The originator of the mail was Oslo barnehagen [Oslo kindergarten], located at 'The Oslo City Department of Education and Knowledge'. The pamphlet further states that the bureaucratic administrators of Oslo-kindergarten have established a standard for good language environment in which every year all kindergartens shall assess and further develop their language environment. The measures are considered in connection with kindergartens' annual plan. In addition, there is a soon to be introduced Oslo-standard for the systematic monitoring of children's language development.

${ }^{4}$ http://ec.europa.eu/ploteus/search/site?f[0]=im_field_entity type\%3A97 [read 07.11.14]
} 
account, as interpreted from the Foucauldian perspective, the first level can be read as open, but far from empty. It is not empty because there are already expectations of children's learning outcomes connected to the kindergarten, even though this is not made explicit. Despite the fact that children's skills are not made explicit in the national regulations, neither in the national curriculum nor in the Norwegian Qualifications Framework, the pamphlet in the text-cut above shows how making assessments of children's skills may be adopted through the sector's bureaucratic conditions and regulations.

The text-cut is an example of how new bypasses and options in the use of surveillance techniques are implemented to admit and encourage control over the youngest citizens' language skills. Contours of this can be observed in the second text example, which states the aim that all children should have adequate proficiency in Norwegian in order to follow basic training when they start school. This is followed by another statement that $25 \%$ of children do not master the Norwegian language before entering primary school. The pamphlet calls for the use of technology to assess and surveil whether the goals are achieved, which is stated as a 'follow-up' [oppfølging]. The staff are further invited to enrol for a seminar to learn how to conduct the measurements required to 'follow up'.

The tools to conduct the 'follow up' are linked to a detailed registration schema. Here, the municipality of Oslo follows global trends in urging the practice of registration of children's skills and learning outcomes. Kindergarten teachers are offered support for their practice through the use of manuals for mapping. In Oslo, these teachers are further offered a seminar to learn how to use one of the most distributed schemas for the registration of children's language skills in Norway - 'TRAS'5 (tidlig registrering av språkutvikling [early registering of language development]. In the handbook connected to the schema, the kindergarten teacher and the kindergarten are described as lacking in traditions of formal registration of language skills. A circle with 72 rubrics for shading support a detailed registration of each child's social and communicative development in the Norwegian verbal language. This mapping of skills is read here as an act of monitoring and a conduction of surveillance over children's learning outcomes.

\section{Presenting kindergarten teachers' statements}

Following Foucault, I point to the leaky nature of bodily aspects and the manner in which they present as linked elements of a greater ensemble in which new kindergarten procedures accomplish new conditions through the forms of subjectification, games of truth and practices of power (Varela, 2001, p. 113). In my ongoing study (Ulla, 2011; 2012; 2014), I question the manner in which the statements made by kindergarten teachers refer to their bodies in professional procedures of identification and, further, how they conduct forms of subjectification. Through statements from kindergarten teachers, I have problematised the eye as an arrangement connected to forms of subjectification.

The kindergarten teachers in the study acted critically towards the schemas manufactured for their practice, and they did not embrace the tasks stipulated by the municipality. Rather, they detailed their skepticism of the seminar and schemas and were critical of the formal registration and mapping of children's skills, struggles, behaviors and development. They distanced themselves from the schemas, or more specifically, they distanced themselves from the shading skills in the standard schemas mentioned earlier. Even though the kindergarten teachers tried to distance themselves from the schemas, worries concerning individual children grew. The teachers did not distance

\footnotetext{
${ }^{5}$ TRAS: http://www.statped.no/Tema/Sprak/Publikasjoner/TRAS-Observasjon-av-sprak-i-daglig-samspill// [read 31.10.14]. Ninety percent of all Norwegian kindergartens have experiences of practising this mapping manual (Østrem et al., 2009; Rambøll, 2008).
} 
themselves from the task of identifying and administrating children's individual learning processes, and they used the categories in the schemas to support their identification practices. As one of the kindergarten teachers stated:

Det skal ikkje brukast på barn under tre år. Det er det som er sagt. Eg har brukt det av og til, berre for å sjå kvar barnet ligg, men eg har aldri fylt det ut på barn under tre år. Det har eg ikkje gjort. Men eg har brukt det som eit verktøy for meg sjølv. Utan å drive og skravere, liksom. Berre for å finne ut litt kva vi må jobbe med då, for eksempel. For min eigen del.
English translation: It should not be used on children under three years. That is what has been said. But I've used it occasionally, just to see where the child is situated, but I have never used it on children under three years. I've not done that. But I've used it as a tool for myself, without conducting the shading. ...only to find out a little bit of what we have to work on; it's for my own sake.

My interpretation of this statement is that the stability of the eye seems firmly leaking affected by the schema, and the seeing grows like a gazing procedure. The eye becomes a brick in an arrangement of examination supported by the schema and plays a central role in knowledge construction. I am particularly curious about how bodies can be read if they are placed at the centre of attention in relation to power technology. Based on this, I do not read the eye of the kindergarten teacher as a passive perceptual conveyor of knowledge but rather as the performance of policy. This methodological approach helps me address how a set of statements comes to constitute objects and subjects (Peräklyä \& Ruusuvuori, 2011, p. 531) and, particularly, how statements of, about and addressed to kindergarten teachers constitute both objects and subjects. In the statement above, the kindergarten teacher underlines that the categories in the schema support her eye. Moreover, she insists on it being an act for her own sake - not for that of the child. She further makes an explicit distinction between her, the child and the schema and refers to the schema as providing more of a private affair than a policy commitment. I chose to read this as being closely connected to how human beings are made into subjects, as described by Foucault (1982/1994). Foucault's theories of subjectification perform the function of a thinking tool, which, as Jackson and Mazzei (2012) point out, can be an effort to interrogate the rationality of the present, as in the case of power or knowledge readings (Jackson \& Mazzei, 2012, p. 65).

\section{The dispositive/apparatus}

Foucault (1977/1980) uses the concepts of the dispositive and the apparatus to identify heterogeneous correspondence between orders of discourse and to point to heterogeneous relations that come to play in the genesis, or re-formation, of a practice or an institution, among others. Throughout, he connects this concept to the intertwined conditions of power and knowledge:

The apparatus is thus always inscribed in a play of power, but it is also always linked to certain coordinates of knowledge which issue from it but, to an equal degree, condition it. This is what the apparatus consists in: strategies of relations of forces supporting, and supported by, types of knowledge. (Foucault, 1977/1980, p. 196)

Foucault's work has built the foundation for how power and knowledge come into play in the construction of modern welfare institutions. By building further on Foucault's theoretical and methodological contributions, I can focus on one of the modern welfare institutions in Norway: kindergartens. It is not a question of whether learning outcomes are controlled in contemporary kindergartens, and neither does the study I undertake contribute to a complete explanation of why the surveillance of childhood has come to be. Instead, by drawing on the concept of dispositive 
ensembles, I question and dwell upon how the surveillance of children's skills occurs in everyday life and, specifically, through bodies in kindergarten. In this way, the study contributes nuances regarding how surveillance is installed in contemporary kindergartens in a time and space where pedagogy has come to be a podium for public politics targeting the testing and administration of individuals. The concept of the dispositive may methodically support this activity. I can further shed light on how surveillance may be installed in kindergartens from a bodily perspective by further building on Foucault's theories:

[...] Foucault stresses how the body is involved in relations that are political not only in an implicit sense, but explicitly and consciously so. The body is an object of techniques and strategies that bear on its materiality in order to channel it, train it, mould it and subject it, rendering the body 'docil' for economic or military purposes. Foucault names 'political technology of the body' a form of knowledge that is at once politically interested, and yet true to the materiality it seeks to affect. (Fraser \& Greco 2005, p. 71)

I dwell upon the micro-mechanisms in the heterogeneous arrangements of practise. More specifically, I read bodily aspects as bricks in this mechanism. Dispositive analyses do not provide an interpretation of a given practice; rather, they devote attention to social constructions on a different level. I question how the dispositive functions as a meeting point for discipline and governmentality as well as how it deposits through bodily practise. By problematising how bodies intertwine in the surveillance of children in kindergarten, I have read eyes, hands and shoulders not only as bodily components but also as leaky components of a disposition. I do not write about the body but, rather, about how bodily events and manoeuvrability are linked across objects and discourses. Following Haraway (1991), this has required me to resist the idea of the stable, individualised human subject with isolated bodies encapsulated by skin. Here, I do a crossover from poststructuralism to the theoretical contributions of posthumanism, which support me methodologically as I explore these possibilities. A posthuman theory opens new possibilities through a re-thinking and destabilisation of the position of the isolated human subject. Plaiting these perspectives into the study leads me to further question how an isolated individual child is constructed in the schemas. This is linked to how the schemas speak of stable skills and individuals, separated by both squares and skin. It states both children and language as divisible into series of age classifications. It further produces the images of children as a case to administer and distribute, and images of language skills as possible to examine by a gazing eye.

Approaching such theories from both poststructuralism and posthumanism helps me to methodologically re-think ideas of stability and to open my mind to ideas of discontinuity. Early childhood educators are intertwined with the transformation of kindergartens in contemporary global policy conditions, and this methodological approach allows me to dwell upon the instability and leakiness of both subjects and objects. Here, I also follow Rhedding-Jones (2008, p. 29) who problematises the manner in which an epistemological dissonance between public policy and early childhood education and practice may be linked to positivism and the security of fixedness. Through her postmodern, mixed-genre text, as well as through Foucauldian perspectives, she critically examines the yearning of public policy for stability and solutions, which are 'set up in the name of early childhood education's international policy development' (Rhedding-Jones, 2008, p. 29). Changes and developments in early childhood education do not take place as silky-smooth processes, and Foucault (1977/1980b, p. 112) points to discontinuities in the rhythms of the transformations. The system of relations between each element in the construction and re-construction of the kindergarten can be viewed as a discontinuous and heterogeneous ensemble:

What I'm trying to pick out with this term is, firstly, a thoroughly heterogeneous ensemble consisting of discourses, institutions, architectural forms, regulatory decisions, laws, administrative measures, scientific statements, philosophical, moral and philanthropic 
propositions - in short, the said as much as the unsaid. Such are the elements of the apparatus. The apparatus itself is the system of relations that can be established between these elements. (Foucault, 1977/1980a, p. 194)

The system of relations established between these elements is as discontinuous as each element, and it does not stabilise. The dispositive is always under transformation, and this transformation may also be identified as a contour in certain historical moments. By identifying certain historical moments, it is possible to read as immanent not only everyday micro elements but also macro elements of the kindergarten. By making this methodological choice, I resist reading the macro level as a superior transcendental shape and, instead, insist on switching my analysis between elements traditionally separated as contrasts.

\section{Rhythms of transformations}

Kindergartens are recognised as welfare institutions in Norway and are targeted as part of public educational policy. The Norwegian kindergarten has undergone massive changes not only with regard to its contest but also through a major expansion of the institution, which is closely connected to kindergartens becoming a focused target of public policy. Kindergartens may still be working in the shadow of compulsory schools, but public policymakers' interest has been transforming and increasing. Foucault (1977/1980b) points to discontinuity in the rhythms of transformations, and he provides a thorough analysis of how changes and developments do not take place as silky-smooth processes (Foucault, 1977/1980b, p. 112).

Kindergartens are set to respond to an urgent need to re-shape childhood for the youngest children in Norway. During the period 2003 to 2013, the number of Norwegian kindergartens has grown exponentially. The transformation of kindergartens in Norway may be viewed as rapid and extensive throughout the last decade. Foucault asked the question: 'How is it that certain moments and in certain orders of knowledge, there are these sudden take-offs [...]?' (Foucault, 1977/1980b, p. 112). A sudden take-off most certainly occurred in 2003 when a governmental conciliation was designed to enable the state to focus on a major expansion of kindergartens. From 2003 through to 2008, Norwegian state grants to the sector increased from $0.5 \%$ to $0.8 \%$ of GDP (which is equivalent to an increase from NOK 4.5 billion in 2000 to NOK 24.3 billion in 2009). Moreover, every child over the age of one was offered the legal right to a place in kindergarten (OECD, 2012, p. 59). The reform was financed through earmarked grants, which made it possible to increase the percentage of eligible children attending kindergarten to $98 \%$. Over the last ten years, the number of children in Norwegian kindergartens has nearly doubled, thus marking a turnaround regarding political interest in the sector.

This has resulted in a re-organising of early childhood in Norway. Moreover, together with the changes in tasks, these shifts also connect with the bodily aspects surrounding and segmenting kindergarten knowledge. By allowing Foucault's work to inform the process of constructing an analysis, the study may promote a critique of power, truth and strategy in the sense that following the critical contribution of early childhood researchers' challenges - 'who gets to say what and where' (Rhedding-Jones, 2008, p. 31). In line with this thinking, Krejsler (2013) points to how dominant evidence-based discourses have weakened the voices of professionals in the field of education, stating that 'professionals appear to have less of a say as opposed to policy-makers and administrators' (Krejsler, 2013, p. 22). By addressing these issues in the specific context of the professionals working within kindergartens, I choose to turn the focus towards how kindergarten becomes the locus of surveillance and how the play of reformations materialises its effects. This methodological strategy makes it possible to further critique how elements of the dispositive interweave in the grip and tempo of the hands and in the sounds of the throat and tongue. Both subjects and objects are speaking and being spoken, writing and being written. In line with this, I can 
read statements and procedures relating to sitting, sleeping, starving and staring as acts of politics, knowledge and power and as elements in an arrangement I choose to call the dispositive.

Politics exists not only in the demands of official documents or through the work of top-down movements. The practice and procedures of mapping the youngest children's skills have made headway into kindergartens through other channels beyond the strict 'top-down' entrance. Documents issued at the governmental level are written in slippery language whereby the mapping of children's skills has never been explicitly implemented. Rather, it has been suggested as a unique opportunity, as in the following example. The text-cut is from a White Paper titled Quality in Kindergarten (Kunnskapsdepartementet, 2009, p. 97):

\begin{tabular}{|c|c|}
\hline $\begin{array}{l}\text { God språklig og sosial kompetanse er } \\
\text { grunnleggende for å kunne ta aktivt del i et } \\
\text { demokratisk kunnskapssamfunn. Barnehagen } \\
\text { har en unik mulighet til å oppdage barn som av } \\
\text { ulike grunner har språkvansker eller forsinket } \\
\text { språkutvikling. } \\
\text { Forskning viser at forskjeller i språklig } \\
\text { kompetanse ved skolestart fortsetter og til dels } \\
\text { forsterkes i } \\
\text { skolen. Språkstimulering før skolealder } \\
\text { reduserer } \\
\text { behovet for og kostnadene til } \\
\text { spesialpedagogiske } \\
\text { tiltak i skolen. } \\
\text { [...] } \\
\text { Formålet med språkkartleggingen skal være å } \\
\text { sikre at barnehagene oppdager alle barn som } \\
\text { har behov for særskilt språkstimulering. } \\
\text { Kartlegging er med andre ord ikke et mål i seg } \\
\text { selv, men et utgangspunkt for å gi barn som } \\
\text { trenger ekstra oppfølging god og tidlig hjelp. }\end{array}$ & $\begin{array}{l}\text { English translation: Good language and social } \\
\text { competence are essential in order to } \\
\text { participate actively in a democratic knowledge } \\
\text { society. The kindergarten has a unique } \\
\text { opportunity to discover children who, for } \\
\text { various reasons, have language difficulties or } \\
\text { delayed language development. Research has } \\
\text { shown that differences in language competence } \\
\text { when enrolled in school continues and worsen } \\
\text { during school. Language stimulation before } \\
\text { school age reduces the need for, and the costs } \\
\text { related to, special pedagogical measures in } \\
\text { school. } \\
\text { [...] } \\
\text { The purpose of the language mapping will be to } \\
\text { ensure that kindergartens identify all children } \\
\text { who need special language stimulation. } \\
\text { Mapping is, therefore, not a goal in itself, but a } \\
\text { starting point to give children who need } \\
\text { additional follow up good and early help. }\end{array}$ \\
\hline
\end{tabular}

The justification for the mapping exceeds its energy through the construction of identifying the child in need of help. Surveys have shown that over $90 \%$ of kindergartens monitor children's learning outcomes ( $\varnothing$ strem et al., 2009; Rambøll, 2008). Processes of justification can be closely linked to rationality and to the circumstance in which [...] "practices' don't exist without a certain regime of rationality' (Foucault, 1980/1991, p. 79). The practices of monitoring the competences and skills of one-, three- or six-year-olds are closely linked to an understanding of children's legal right to achieve strong language skills before entering primary school - a right that is explicitly stated in the policy documents of kindergartens.

Foucault (1977/1980a) points to this element of the apparatus as follows:

Thus, a particular discourse can figure at one time as the program of an institution, and at another it can function as a means of justifying or masking a practice which itself remains silent, or as a secondary re-interpretation of this practice, opening out for it a new field of rationality. (Foucault, 1977/1980a, pp. 194-195) 
Kindergarten staff members are responding to a prioritised area that has been intersecting their profession over the last decade: to prepare the language of children before they enter primary school and to ensure that the children have achieved 'good' language and social competences when they leave kindergarten. Throughout the documents, the statements concerning 'good language' are used synonymously with those concerning 'mastering an adequate level of Norwegian oral language'. The staff members respond to the prioritised area by ensuring that the children are learning and achieving 'good' language. Through the use of schemas, the staff members of the kindergartens are dealing with a decisive problem that, in Foucault's terms, may be described as a new field of rationality. The arrangements of schemas of skills are connected to the technologies of the institutions, which come in addition to staff members' answerability and responsibility. Staff members' ability to observe children who do not achieve 'good' language is supported by the technology of the schemas made for this purpose.

Working through this methodological approach has involved analyses of language and policy discourses. It has further involved analyses of how kindergartens, children and kindergarten teachers are being spoken to and written about as well as how arguments encircle, crash and/or reveal traces of rationality. In conducting my analyses, I have linked the processes of justification closely to the reshaping of rationality and to the concept of the dispositive.

\section{Games of truth and practices of power}

As previously noted, I began this study with the aim to contribute new aspects of kindergarten teachers' knowledge, judgment and practice in relation to the increasing demand for mapping children's skills in contemporary kindergartens. Reading and writing following the example of Foucault have made me less able to separate knowledge from judgment and practice. Exploring concepts of judgment and practice have also led me to problematise knowledge, and vice versa (i.e. exploring concepts of knowledge have led me to problematise judgment and practice).

Foucault distinguished between savoir and connaissance as types of knowledge (Foucault, 1969/2002). The distinction is not made to separate these two types of knowledge but to point to how they work as a couplet. Savoir is referred to as a general and underlying condition of knowledge regarding connaissance (i.e. a discipline as pedagogic). Given Foucault's distinction between these two aspects of knowledge, these concepts may help me to research how the judgment and practice of kindergarten teachers become legitimated as well as how possibilities of pedagogy become reshaped. This is not causality (as if savoir were the cause of connaissance); rather, Foucault used the term to describe how acts of connaissance affect savoir.

The discursive formation of the schema represents a locus of savoir and impacts the relationship between the kindergarten teacher, the schema and the formal rules that govern both. The kindergarten teacher's performing eye maneuvers as it is governed by the theoretical strategies of the schema, referring to it as a support for her own sake. The eye thus becomes an arrangement, weaving together processes of subjectification with the game of truth and the practice of power. The kindergarten teacher uses her eye to perform optimal identification, support and administration of the youngest human beings in the kindergartens. The body thus becomes an indicator in the games of truth as well as in the practice of power. The processes of identification are elements of a play of power and knowledge in relation to those discursive conditions that are necessary to produce the identifying gut feeling and gaze of the kindergarten teacher. Foucault incorporates this gaze in order to conceptualise how power operates through people and objects. Under the inspecting gaze, 'each individual under its weight will end up by interiorising to the point that he is his own overseer, each individual thus exercising this surveillance over, and against, himself' (Foucault, 1977/1980c, p. 155). The observing eye functions as a form of technology in the machinery of discipline. However, the eye is not limited to the kindergarten teacher's body; it is also 'an eye of a political anatomy'. 


\section{Plaiting problematisation and passion}

By employing this research approach, I have chosen not to contribute with an expert voice and front solutions to the issues. Here, I follow Foucault (1969/1977) in being sceptical of the individual author; then again, referring to Foucault: writing is an act of limiting, excluding and choosing. I have however chosen to problematise and provide scepticism through a mixture of the genres of continental philosophy and critical pedagogical research as this creates new possibilities regarding critical pedagogy (Sandvik, 2013, p. 27). In this methodological article, I have concentrated the discussion on the concept of apparatus as a tool to perform critical research into how power and knowledge come into play in micro elements of everyday life in kindergarten.

By exploring how Foucault's concepts of the dispositive and the apparatus might be put to work methodologically, I have attempted to suggest how the bodily event of an eye, the categories and techniques of a schema and the discourses of early childhood public policy may be the contours of a dispositive ensemble. An eye event can construct passages that question the production of the identifying gaze of kindergarten teachers. I have read Foucault's concept of the dispositive, and related to this is the net linking 'certain coordinates of knowledge which issue from it but, to an equal degree, condition it' (Foucault, 1977/1980, p. 196). This has been useful in my study of the reshaping of kindergartens as well as of kindergarten teachers' knowledge and professional practices. Further, it has opened up the possibility of questioning the close relationships of power and knowledge in the increasingly emerging practices and policies of mapping children's skills in Norwegian kindergartens. This choice of methodology has made it possible to problematise how constitutions of disciplinarian forces are produced through the relations of power, knowledge and bodies.

The study has involved a methodological journey in which continental, critical theories have been used as guiding forces. In particular, Foucault's theories have served as tools with which to carry out the research. As pointed out earlier, the text is primarily rooted in poststructuralism, even though some roots reach into constructions of posthumanism. However, it was Professor Jeanette RheddingJones who introduced me to the work of Foucault and gave me my first access to this methodological pathway to critical research. She further introduced me to feminism, poststructuralism and, later, posthumanism. Through her cooperative writings, talks, lectures, listening and supervising, she supported me in my construction of a portal into questioning social justice in the context of early childhood education and care. Now, I use this knowledge to construct my methodological choices. Rhedding-Jones has critically addressed how the voices of 'experts' entangle in public policy. In 2008, Rhedding-Jones published an academic play, which I refer to as a key text (Rhedding-Jones, 2008). Her academic discussion was informed by Foucault as a key thinker, and she played with texts as she played with concepts and issues:

Not only do I play with how texts can work in postmodernity; I also make a pun of a key theme of much early childhood practice and the accepted rhetoric of what must be known as good practice. (Rhedding-Jones, 2008, p. 29)

Working methodologically through the critical perspective presented by Rhedding-Jones has made it possible for me to extract and dwell upon the discursive configurations and reconfigurations of the epistemic conditions regarding kindergartens teachers' professionalism. She has inspired me to follow my theoretical passion and supported me in the construction of a passage through which to research contemporary kindergartens. Early childhood education research is not the act of an isolated individual. Rather, the methodological choices interweave themselves into the text, just as they further interweave with practical problems, positions and passions. 
Even if the computer on which I have written this text is touched only by my fingertips, the author of this text goes beyond the silhouette of my body.

\section{Acknowledgements}

The text is a rewrite of a co-authored abstract written in 2011 with Professor Jeanette RheddingJones. This abstract was titled: Over-Standardisation of Young Children's Language 'Skills': Ideas and Issues from Norway. The original abstract requested resistance to the de-skilling, un-doing, dumbing down, demystification and regimentation of kindergarten teachers' knowledge. Further, the abstract issued framings of kindergarten teachers through instrumental discourses, examining when the teachers were pushed to measure control over young children. The original abstract never developed into a full text. The text has now been re-constructed and incorporated into my ongoing Ph.D. work, which I never could have written without the love, guidance and spirit of Jeanette. In addition to mentoring me, she also introduced me to the work of Foucault.

\section{References}

Arnesen, A.-L., \& Lundahl, L. (2006). Still social and democratic? Inclusive education policies in the Nordic welfare states. Scandinavian Journal of Educational Research, 50(3), 285-300. http://dx.doi.org/10.1080/00313830600743316

Bloch, M. N, Holmlund, K., Moqvist, I., \& Popkewitz, T. (2003). Governing children, families and education. Restructuring the welfare state. New York: Palgrave Macmillan.

Bussolini, J. (2010). What is a dispositive? Foucault Studies, 10, 85-107.

European Commission (2008). The European Qualifications Framework for Lifelong Learning, (EQF). 2008/C 111/01, protocol 31.

Foucault, M. (1980a). The confession of the flesh. In C. Gordon (Ed.), Power/knowledge. Selected interviews and other writings 1972-1977 by Michel Foucault (pp. 194-228). New York: Pantheon Books. (Original work published 1977)

Foucault, M. (1980b). Truth and power. In C. Gordon (Ed.), Power/knowledge. Selected interviews and other writings 1972-1977 by Michel Foucault (pp. 109-133). New York: Pantheon Books. (Original work published 1977)

Foucault, M. (1980c). The eye of power. In C. Gordon (Ed.) Power/knowledge. Selected interviews and other writings 1972-1977 by Michel Foucault (pp. 146-165). New York: Pantheon Books. (Original work published 1977)

Foucault, M. (1991). Questions of method. In G. Burchell, C. Gordon \& P. Miller (Eds.), The Foucault effect. Studies in governmentality. With two lectures by and an interview with Michel Foucault (pp. 73-86). Chicago: The University of Chicago Press. (Original work published 1980)

Foucault, M. (1994). The subject and power. In J. D. Faubion (Ed.), Power (pp. 326-348). New York: The New Press. (Original work published 1982)

Foucault, M. (2002). The archaeology of knowledge. London: Routledge. (Original work published 1969)

Foucault, M. (1977). What is an author? In D. F. Bouchard (Ed.), Language, counter memory and practice: Selected essays and interviews by Michel Foucault (pp. 113-138). New York: Cornell University Press. (Original work published 1969)

Fraser, M., \& Greco, M. (2005). The body. A reader. London and New York: Routledge.

Haraway, D. (1991). A cyborg manifesto science, technology, and socialist-feminism in the late twentieth century. In D. Haraway (Ed.), Simians, cyborgs and women: The reinvention of nature (pp. 149-181). New York: Routledge. 
Jackson, A. Y., \& Mazzei, L. A. (2012). Thinking with theory in qualitative research: Viewing data across multiple perspectives. Abingdon, Oxon: Routledge.

Jensen, B. (2009). A Nordic approach to early childhood education (ECE) and socially endangered children. European Early Childhood Education Research Journal, 17(1), 7-21. http://dx.doi.org/10.1080/13502930802688980

Krejsler, J. B. (2013). What works in education and social welfare? A mapping of the evidence discourse and reflections upon consequences for professionals. Scandinavian Journal of Educational Research, 57(1), 16-32. http://dx.doi.org/10.1080/00313831.2011.621141

Kunnskapsdepartementet [Ministry of Education] (2011a [2006]). Rammeplanen for barnehagens innhold og oppgaver [The framework plan for the contest and tasks of Kindergartens; in Norwegian] [Laid down by the Ministry of Education and Research 1 March 2006, amended by Regulation 10th of January 2011 No. 51]. Oslo: Kunnskapsdepartementet.

Kunnskapsdepartementet [Ministry of Education] (2011b). Nasjonalt kvalifikasjonsrammeverk for livslang læring [Norwegian qualification framework for lifelong learning, NQF; in Norwegian] [Laid down by the Ministry of Education 15 December 2011]. Oslo: Kunnskapsdepartementet.

Kunnskapsdepartementet [Ministry of Education] (2009). St.m. nr. 41 (2008-2009). Kvalitet $i$ barnehagen [White Paper No 41 (2008-2009) Quality in ECEC; in Norwegian]. Oslo: Kunnskapsdepartementet.

Kunnskapsdepartementet [Ministry of Education] (2006 [2005]). Barnehageloven. [Kindergarten Act; in Norwegian]. Oslo: Kunnskapsdepartementet.

OECD [The Organization for Economic Co-operation and Development] (2012). Starting Strong III: A quality toolbox for early childhood education and care. OECD Publishing.

Otterstad, A. M., \& Braathe, H. J. (2010). The Nordic social pedagogical tradition in early childhood education and care meeting readiness for school discourses. Procedia-Social and Behavioral Sciences 2, 3023-3030. http://dx.doi.org/10.1016/j.sbspro.2010.03.458

Peräklyä, A., \& Ruusuvuori, J. (2011). Analyzing talk and text. In N. K. Denzin \& Y. S. Lincoln (Eds.) The SAGE handbook of qualitative research (pp. 529-544). Los Angeles: Sage.

Popkewitz , T. S. (1998). Dewey, Vygotsky, and the social administration of the individual: Constructivist pedagogy as systems of ideas in historical spaces. American Educational Research Journal, 35(4), 535-570. http://dx.doi.org/10.3102/00028312035004535

Rambøll Management (2008). Kartlegging av språkstimulering og språkkartlegging i kommunene. [Mapping of language stimulation and language ability mapping in municipalities; in Norwegian]. Oslo: Rambøll Management.

Rhedding-Jones, J. (2008). The OECD and the notion of expert in early childhood education and care: A play. International Critical Childhood Policy Studies, 1(1), 28-41.

Sandvik, N. (2013). Medvirkning og handlingskraft i småbarnspedagogiske praksiser. Horisontalt fremforhandlet innflytelse. [Ph.D. Thesis.] NTNU, Trondheim.

Solbrekke, T. D., \& Østrem, S. (2011). Profesjonsut øvelse mellom profesjonelt ansvar og regnskapsplikt. Nordic Studies in Education, 31(3), 194-209.

Ulla, B. (2014 [in press]). Auget som arrangement - om blikk, makt og skjønn i profesjonsutøvinga til barnehagelæraren. Nordisk barnehageforskning [Journal of Nordic Research in Early Childhood Educational Research].

Ulla, B. (2012). Kroppens kraft - kropp som del av inkludering og profesjonsutøvelse i barnehagen. In A-L. Arnesen (ed.) Inkludering -perspektiver i barnehagefaglige praksiser (pp. 126-148). Universitetsforlaget: Oslo.

Ulla, B. (2011). Omsorgens omfattende områder - Kritiske refleksjoner om omsorg i barnehagen. In A.M. Otterstad \& J. Rhedding-Jones (eds.) Barnehagefaglige diskurser (pp.70-83). Universitetsforlaget: Oslo.

Varera, J. (2001). Genealogy of education. In T. Popkewitz, B. M. Franklin, \& M. A. Pereyra (Eds.), Cultural history and education. Critical essays on knowledge and schooling (pp. 107-124). New York and London: Routledge. 
$\emptyset$ strem, S., Bjar, H., Rønning Føsker, L., Dehnæs Hogsnes, H., Thorsby Jansen, T., Nordtømme, S., \& Rydjord Tholin, K. (2009). Alle teller mer. En evaluering av hvordan Rammeplan for barnehagens innhold og oppgaver blir innført, brukt og erfart [A report reviewing how the national curriculum for the content and tasks are introduced, applied and experienced in Norwegian kindergartens]. Tønsberg: Høgskolen i Vestfold. Barnehagesenteret. 